J O UR N A L

OF FESTIVE

STUDIES
THE MATERIALITY OF FESTIVITY

\section{Processional Culture and Black Mobility in Maggie Washington's Wilmington}

\section{Elijah Gaddis}

Auburn University, United States

\section{KEYWORDS}

material culture

landscape

mobility

Jonkonnu

postbellum US South

\section{ABSTRACT}

This article addresses changes in the built environment of the postbellum American South through an examination of the life histories, parade routes, and costuming practices of the Afro-Caribbean Jonkonnu masking tradition. I juxtapose the stories of two practitioners of the tradition across the color line in turn-of-the-twentieth-century Wilmington, North Carolina. Using a material culturally inflected approach to the study of landscapes, I use these two narratives to deepen the histories of African American processional cultures toward a longer time span and a more immersive, performer-oriented approach. Though few conventional objects of ornamentation and display from these practices survive, this article posits that an approach rooted in the materiality of landscape can help uncover festive cultures that have been understudied or undertheorized in more conventional historical approaches. Further, the ubiquitous presence of Jonkonnu and other Black processional traditions in the postemancipation city suggests the importance of these and other objects, practices, and larger cultures of celebration in combating white supremacist culture. 


\section{$J O U R N A L$}

OF FESTIVE

\section{STUDIES}

1. "Woman Was Masquerading," Wilmington Morning Star (Wilmington, NC), December 28,

1911.

2. Wilmington, N.C. Directory, 1905 (Richmond, VA: Hill Directory, 1905), 211, 239.

3. Depending on its time and place of celebration, Jonkonnu could go by any number of names. In North Carolina in particular I have documented John Kuner, Kuner John, John o'Cooner, Jonkonnu, cooners, and John Canoe. As I note later in this article, these names were largely interchangeable, with the racialized "coon"-derived words coming after white appropriation of the practice.

4. Though space does not permit me a full explication of Jonkonnu in its various forms throughout the Caribbean, it is a topic amply documented by anthropologists, art historians,

folklorists, and historians in particular. Early efforts at verbal

and pictorial descriptions of

the practice occurred as early

as the late eighteenth and early nineteenth centuries, respectively,

in Edward Long, The History of Jamaica (London: Printed for

T. Lowndes, 1774); and Isaac Mendes Belisario, Sketches of Character in Illustration of the Habits, Occupation and Costume of the Negro Population in the Island of Jamaica (Kingston, Jamaica: Published by the artist at his residence, 1837-38). Early twentieth-century scholars were likewise drawn to the practice as both a historical and ongoing tradition. See,

for instance, Martha Warren Beckwith, Christmas Mummings

\section{Processional Culture and Black Mobility in Maggie Washington's Wilmington} Elijah Gaddis

In the early hours of December 27, 1911, Maggie Washington went to jail dressed in her best masquerading costume. The details of her arrest were peculiar. Police picked her up at an intersection that did not appear on any of the maps that were both documenting and dictating Wilmington, North Carolina's turn-of-the-century growth. Added to this absence was the next morning's newspaper report that she was "masquerading in men's attire." With uncharacteristic detail, the article described Washington as "colored, of unsavory reputation" and went on to explain her arrest as a result of her being "far from her base of operations" and with "no permit to masquerade."1

Five years earlier, twelve-year-old Henry McKoy likewise took to the streets at Christmastime dressed in outrageous garb. McKoy was white, the son of a local attorney. His own attire-a blackface mammy caricature-represented its own series of violations, though ones that were encouraged rather than policed. In costume, he paraded from house to house across Wilmington, giggling with his friends as they filled themselves on rich food and drink. He ended his night safely back at home on Third Street, a half mile away from the prison where Washington would spend her holiday evening five years later. ${ }^{2}$

Both Washington and McKoy were on the streets of Wilmington to take part in an evolution of the masked holiday processional called Jonkonnu. What began in the Caribbean as a carnivalesque practice of enslaved people transitioned first to the plantations of the antebellum South and then to the streets of Wilmington and other North Carolina cities in the postbellum era. By the early twentieth century, the practice was appropriated by white men and boys as a form of popular minstrelsy. That act of appropriation was one in a long line of actions, both sudden and gradual, that attempted to reconfigure Wilmington as a place hostile to African American people. The life of Maggie Washington, and particularly her performance of Jonkonnu, is a story of the way that Black people navigated a city increasingly defined by spatial and infrastructural white supremacy. The story of her processions through the city-both in celebratory formations and in more everyday movement-highlights broader changes to and bodily navigational strategies in the postbellum built environment. Her engagement with the materiality of a place physically changing highlights the strategic role of festive cultures within the emergent Jim Crow United States. This is a story told in the literal and metaphorical space between McKoy and Washington, hewing toward people and places made marginal in an attempt to explain the material and spatial manifestations of power, celebration, and festivity.

\section{Jonkonnu and Postbellum Processional Culture}

The headline in the Morning Star the day after Washington's arrest was immediately comprehensible to its readers: "Woman Was Masquerading." To residents of early twentiethcentury Wilmington, and a significant part of the South, this was a clear reference to the performance of an ancestral holiday tradition. Jonkonnu (alternately John Canoe, John Kuner, or any number of similar variations) was an annual masked procession that revolved around the Christmas holidays. ${ }^{3}$ Its origins in the colonial spaces of the Caribbean are well documented. ${ }^{4}$ 


\section{$J O U R N A L$ OF FESTIVE}

\section{STUDIES}

in Jamaica (New York: American Folk-Lore Society, 1928). More recent scholarship has dealt with the practice throughout the Caribbean in both contemporary and historical contexts and from a variety of disciplinary viewpoints. See, for instance, Kenneth Bilby, "Surviving Secularization: Masking the Spirit in the Jankunu (John Canoe) Festivals of the Caribbean," New West Indian Guide 84, nos. 3-4 (December 1, 2010): 179-223; Laura M. Smalligan, "An Effigy for the Enslaved: Jonkonnu in Jamaica and Belisario's Sketches of Character," Slavery \& Abolition 32, no. 4 (2011): 561-81; Michael Craton, "Decoding Pitchy-Patchy: The Roots, Branches, and Essence of Junkanoo," Slavery \& Abolition 16, no. 1 (1995): 14-44; and Robert Dirks, The Black Saturnalia: Conflict and Its Ritual Expression on British West Indian Slave Plantations (Gainesville: University Press of Florida, 1987). Though fewer scholars have looked at the practice on the North American continent, it has received relatively ample consideration given the scarcity of sources. See Geneviève Fabre, "Festive Moments in Antebellum African American Culture," in The Black Columbiad: Defining Moments in African American Literature and Culture, ed. Werner Sollors and Maria Diedrich (Cambridge, MA: Harvard University Press, 1994), 52-63; Lawrence W. Levine, Black Culture and Black Consciousness: Afro-American Folk Thought from

Slavery to Freedom (New York: Oxford University Press, 1977); and Roger D. Abrahams, Singing the Master: The Emergence of Afro-American Culture on the Southern Plantation (New York:

\section{$H$ \\ trutumun}

Less clear is its arrival in North America, or why it appeared almost exclusively in North Carolina. Though the practice was observed by writers there as early as the 1820 s, the most complete accountings of the performance come from the late 1840 s and early 1850 s. ${ }^{5}$ Around the same time that Harriet Jacobs recalled seeing the yearly tradition in coastal Edenton, the white physician Edward Warren left a detailed description of the festival at a large Washington County plantation. ${ }^{6}$ During his sojourn at Somerset in the late 1840s, Warren remembered seeing two stock figures -the Fancy Man and the Ragman-dressed in elaborate costume and leading "a motley crowd of all ages, dressed in their ordinary working clothes." This crowd of people sang and danced in procession to the beat of drums. They moved about the plantation, going from the front door of the enslaver's house to "the young gentlemen's colony, the tutor's rooms, the parson's study, the overseer's house," demanding and receiving monetary tribute at each stop. Here, as elsewhere, this performance was repeated every year, usually on the second day of Christmas, December 26, and typically to a white audience. These were audiences appreciative of Jonkonnu but largely ignorant of its meaning. Jonkonnu in the antebellum South was a celebration to be sure, but like other mumming traditions, it was also a mocking performance of mannered white mastery. The characters adopted by enslaved people poked fun at the airs put on by slaveholders pretending to patriarchal control and cultured manners. In both costume and action, they satirized those performed selves even as they extracted money, food, and drink from these men. This was the carnivalesque enacted: a single night of inverted power that represented a vision of a more equal world. ${ }^{8}$

By Maggie Washington's time, Jonkonnu had transitioned, along with a significant portion of the African American population, to the growing urban centers of North Carolina. As was the case with other African American celebrations, it took on new valences in the postbellum South. It often came to serve as a celebration of freedom and the new licenses of mobility that it allowed. Newspaper accounts throughout North Carolina-mostly on the coast and coastal plain but also as far west as Chatham County, 160 miles inland from Wilmington-reported performances of Jonkonnu in their cities. ${ }^{9}$ Apart from the spatial context of the plantation, Jonkonnu became an act of processional culture that moved its participants through cities marked alike by African American migration and the emerging spatial structures of Jim Crow apartheid. In Wilmington, Jonkonnu emerged as part of a rich culture of public celebration practiced by African Americans. Washington's mobility (and the increasing restrictions placed on it) give us deep insight into how she and other celebrants acted with, among, and against the materialities of these new landscapes.

\section{African American Community and Postbellum Processional Culture}

Maggie Washington was born in February 1887 to Sarah Brewington Washington (born 1865) and Stephen Washington Jr. (born 1859). Her parents were among the first generations of African Americans to grow to maturity in the post-slavery South. They grew up in and lived in Wilmington, a city whose networks of mutual aid and communal solidarity saw the brief flowering of African American political, social, and cultural power. It was the fate of Maggie Washington's generation to see that power systematically and brutally suppressed.

Her family was forged out of the connections made in the meeting rooms and elaborate parades of freedmen's fraternal lodges. Both of her grandfathers were Black working-class men who lived 


\section{$J O U R N A L$ \\ OF FESTIVE}

\section{STUDIES}

Pantheon Books, 1992). Even among the rather smaller set of studies on Jonkonnu in North America, no scholar has dealt with the practice outside of its antebellum origins.

5. Elizabeth A. Fenn, "'A Perfect Equality Seemed to Reign': Slave Society and Jonkonnu," The North Carolina Historical Review 65, no. 2 (April 1988): 132.

6. Harriet Jacobs, Incidents in the Life of a Slave Girl, ed. Lydia Maria Francis Child (Boston: Published for the author, 1861).

7. Edward Warren, A Doctor's Experiences in Three Continents (Baltimore, MD: Cushings \& Bailey, 1885), 201, 202-3.

8. On the carnivalesque, see Mikhail Bakhtin, Rabelais and His

World, trans. Helene Iswolsky

(Cambridge, MA: MIT Press, 1968).

9. "Christmas Items," The Chatham Record, December 28, 1882.

10. US Census, 1870, New Hanover County, North Carolina, Wilmington, p. 50, family 391, Stephen and Phoebe Washington, digital image, Ancestry.com.

11. "Fight among the Samaritans," The Daily Review, November 17, 1879; and "Election of Officers," The Daily Review, July 9, 1879.

12. US Census, 1870 , New Hanover County, North Carolina, Wilmington, p. 96, dwelling 592, family 795 , Henry Brewington.

13. Monroe N. Work et al.,

"Some Negro Members of Reconstruction Conventions and

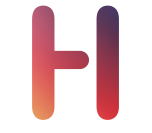

CELEB RATION in the city in the years immediately after emancipation. Stephen Washington Sr. was a carpenter who worked alongside his brother and at least one other man in postbellum Wilmington. ${ }^{10}$ By the late 1870s, he had established himself as a local political figure and a prominent member of the temperance and mutual aid organization the Independent Order of Good Samaritans and Daughters of Samaria (hereafter referred to as the Good Samaritans)..1 One of his fellow members in that organization was Henry Brewington. Brewington (sometimes spelled Bruington) was saddled with the anonymous label of "laborer" in Wilmington's first post-emancipation census. ${ }^{12}$ By 1874 his social standing had changed substantially. In that year he was elected to the North Carolina House of Representatives and served as one of the founding members of the Good Samaritans. ${ }^{13}$ Brewington was thus one of the more prominent members of a large African American community that was quickly founding its own institutions, electing its own officials, and becoming an integral part of a city whose Black population continued to swell in the 1870s and 1880s. ${ }^{14}$ Amid this atmosphere of growth, people like Henry Brewington and Stephen Washington and organizations like the Good Samaritans increasingly took to the streets in an emerging processional culture. These parades marked nearly every imaginable occasion and served as forthright and visible claims to the streets and public places of Wilmington.

Parading was an integral part of the intertwined growth of Black mobility and fraternal culture. Soon after the founding of the first Wilmington chapter of the Good Samaritans in late 1874, they staged their first parade. ${ }^{15}$ These celebratory movements through the city were paralleled by the broader mobilities of new leisure travel by this same class of African Americans. Newspapers of the 1870s and 1880s are filled with news of excursions undertaken by African Americans. Often organized by clubs and organizations, they brought together people who for the first time had both expendable income and the promise of free mobility. Sometimes these outings erupted in long-held intergroup tensions-as when the Wilmington Semi-Weekly Messenger condescendingly blamed an argument among a group of Good Samaritans on an excursion to Raleigh on "too much corn juice."16 More often, these two- or three-day trips brought Black populations of multiple cities together in ceremonies of a shared public culture. Much more ornate than these relatively ordinary expressions of hospitality and brotherhood (and to a lesser, or less-documented, extent sisterhood) were the elaborate parades reserved for intra-lodge meetings that took place with increasing frequency in the 1870s and 1880s. The first such meeting occurred in Wilmington in 1878. The streets were festooned with lodge flags and many of the main streets were full of parading lodge members, clad in full regalia. One of the local papers described the day in great detail on its front page:

The different lodges in attendance ... paraded through the streets yesterday afternoon in full force, headed by the Excelsior Rose Bud Band, the Orators of the Day, Chaplain \&c being in a carriage drawn by four horses. The members were nearly all arrayed in the regalia of the Order and made a very good appearance. The procession marched to St. Stephen's A.M.E. Church, [and heard] appropriate services and ceremonies.... The procession then reformed and marched through our principal streets and thence to the Lodge Room, where it was disbanded. During the day flags were suspended from a line connecting with the Lodge building, at the corner of Second and Princess streets and the house opposite. At night there was a festival at the City Hall. There were quite a number of colored visitors here from Newbern, Raleigh, Goldsboro, and other places. ${ }^{17}$

Other parades like this one followed over the next few years. In 1883, the combined lodges of North Carolina again met in Wilmington, this time with an equally elaborate and somewhat

Journal of Festive Studies, Vol. 3, 2021, 72-91. https://doi.org/10.33823/jfs.2021.3.1.66 


\section{$J O U R N A L$ \\ OF FESTIVE}

\section{STUDIES}

Legislatures and of Congress," Journal of Negro History 5, no. 1

(1920): 78.

14. On this period in Wilmington's history, see Margaret M.

Mulrooney, Race, Place, and Memory: Deep Currents in

Wilmington, North Carolina (Gainesville: University Press of Florida, 2018), 111-73.

15. "The Good Samaritans," Morning Star, May 16, 1878.

16. "Fight among the Samaritans," Daily Review, November 17, 1879.

17. "The Good Samaritans," Morning Star, May 16, 1878.

18. "The Good Samaritans," Wilmington Post, October 12 , 1883.

19. "Good Samaritans," Morning Star, September 9, 1886.

20. "Christmas," Wilmington Post, December 24, 1868.

21. "Black Crook in Newbern," Morning Star, June 9, 1868. larger parade. By that year, the number of lodges in North Carolina had grown to 125, with 250 delegates visiting and parading through Wilmington. ${ }^{18}$ And the institution both in Wilmington and throughout the state only continued to grow in number throughout the decade: the 1886 statewide meeting brought 190 lodges and a full 380 representatives to the streets of Wilmington. ${ }^{19}$ These parades, held at uncertain intervals but with fairly predictable routes, were undoubtedly an annoyance to many city officials. But they proved difficult to regulate for a number of reasons. One was certainly the fact that increasing numbers of African Americans connected to the lodge were gaining political power and taking office in Wilmington. But even the growing political revolution did not lead to much practical power for African American people in the city. Instead, it was the very nature of the procession that allowed them to continue to occur and indeed to grow. This was a parade that was utterly predictable in its route and generally unpredictable in its timing. Unlike many parades that were (and are) pegged to some kind of religious or civic holiday, these processions were both far more regular and much more unpredictable. They could occur as infrequently as the annual meeting or as often as visiting lodges or dignitaries were in town.

Though temporally unpredictable, these Good Samaritan parades were geographically routinized and thus capable of surveillance and implicit regulation. They tended to originate at city hall or other formal sites of civic power and end at the Samaritan Lodge. They were easy to monitor, precisely because they were intended to be highly visible and observable. The material politics of display were important for groups trying to establish institutional power and a larger recognition of their status.

By comparison, Jonkonnu was wild. The practice continued to evolve in the postbellum period as part of the larger culture of everyday and processional Black mobility in the state. Its free roaming route coupled with demands for monetary, alcoholic, or culinary tribute was a threat to propriety and to neatly ordered space. It was impossible for police or other authorities to know where Jonkonnu performers were going as they roamed the city, and so their presence was a significant threat to attempts to monitor and regulate the mobility of Black people in the city.

In the post-Civil War period, the practice of Jonkonnu in Wilmington occasioned a public discourse that was both nostalgic for plantation slavery and dismissive of the celebratory cultures of free African Americans. The year 1868 saw multiple newspapers mention the practice as other Christmas festivities began to be seen and heard throughout the city. The editors of the Post hoped that the firecrackers and other signs of festivity "were not harbingers of 'Johnny Kooners' and the absurd gift beggars that we have seen here on other Christmas days." ${ }^{20}$ Later in the year, the Morning Star took a shot at what they perceived as a provincial newspaper editor's poor taste in the dramatic arts by mockingly suggesting that he had "never seen any performance before except a 'kooner' dance."21 It was a common part of the Wilmingtonians' vernacular and experience and its reappearance each year was expected, sometimes even welcomed. For the most part though, Jonkonnu went largely unremarked. It was part of Christmas celebrations and a fixed feature in the holiday calendar and on the Wilmington landscape.

In 1875, however, the mayor of Wilmington, William P. Canaday, took the first of several strong steps intended to obliterate the practice altogether. A front-page, Christmas Day headline 


\section{$J O U R N A L$ \\ OF FESTIVE}

\section{STUDIES}

22. "No More Kooners," Morning Star, December 25, 1875.

23. "No John Kooners," Daily Review, December 27, 1875.

24. "Christmas in the City," Morning Star, December 28, 1875.

25. "[W. P. Canaday]," Wilmington Post, November 1, 1876.

26. "An Appeal for the Boys," Daily Review, November 15, 1878. declared that there would be "No More Kooners." Anticipating the performance that traditionally took place on the second day of Christmas, Canaday asked the city's main newspapers to spread the word that "no 'John Kooners' will be allowed on the streets to-day nor at any time during the holidays." The banning was accompanied with a strong, specific threat that any performers "will be arrested by the police."22

There is no real indication of how this information was circulated to the African American population of the city, if it was at all. It assumes a kind of regulatory power and in-person enforcement that they certainly would have been familiar with after generations of similarly arbitrary regulation of both performative practice and more everyday forms of mobility. These particular regulations were reflective of a complicated political situation, where both formal political structures and everyday social policing were enforced. In this first year of the ban, at least one newspaper communicated shock at the mayor's decision to "suppress such displays" as Jonkonnu. The same article goes on to claim that "some of the colored churches also ... have resolved against it." ${ }^{23}$ If we can believe this report, it suggests an emerging strain of propriety that viewed an old tradition removed from its former context as improper. This same criticism is inherent in views from the other side of the color line, which was glad to be rid of a "time-honored institution of Christmas which had degenerated into the greatest kind of public nuisance." ${ }^{24}$ Both critiques are premised on an argument about the proper place (materially and conceptually) of African American celebratory culture. Though they were at cross purposes-racial uplift versus racial exploitation-this moment of cohesion suggests the increasingly complicated nature of everyday existence for ordinary Black people in this city.

To that complexity, we can add that the mayor, Canaday, banning Jonkonnu in 1875-77 was a Republican who exhorted "colored men" to "see that your names are properly registered," so that they could vote for him in a failed 1876 bid for Congress. ${ }^{25}$ Hemmed in by an emerging middleclass propriety, Jonkonnu was seemingly threatened on two sides of the color line. A generation earlier, it had been seen as a liberatory celebration of community in the face of enslavement. Now it was seemingly viewed as regressive, a nuisance to white residents of the city who could no longer expect carnivalesque inversion to subside into normative white supremacy after a single day. And Black people were already starting to see the coalitions they had formed fail. Whether or not prominent African American churches did oppose Jonkonnu, their wouldbe Republican partner had banned their practice from the streets. In the process, Canaday revealed both an emerging discourse on the "proper" forms of African American celebration and the paternalistic underpinnings of cross-racial political solidarity. This ideology manifested itself in the increasing regulations around Jonkonnu processions and eventually in the physical infrastructures of the city itself.

\section{Jonkonnu and White Processional Culture}

As the holiday season of 1878 approached, newspapers printed articles decrying the continued ban of Jonkonnu. This nostalgic hue and cry called for a Christmas "such as we had in the primitive days." The holiday at present was "merely a dull holiday, no kooners, can't fire crackers." 26 This was only the first of several such commentaries in subsequent years that sought to paint Jonkonnu as a kind of Black primitivism and as a simple holiday diversion. With the ascendancy of a seemingly secure Democratic majority, the political symbolism 


\section{$J O U R N A L$ OF FESTIVE}

\section{STUDIES}

27. "January 1st, 1879," Morning Star, January 2, 1879.

28. Though my focus here is on Wilmington, there were white imitations and revivals of the practice in other coastal North Carolina cities. Literary historian Richard Walser points to at least one instance of this in New Bern in 1938, and Paul Green includes white cooners in his 1931 play The House of Connelly. Each of these instances were pointing to the earlier white cooner practices around the turn of the century. From this evidence, it seems that the white appropriation of the tradition was relatively commonplace in eastern North Carolina. See Richard Walser, "His Worship the John Kuner," North Carolina Folklore Journal 47, no. 2 (2000): 97-110; Gertrude

S. Carraway, "New Bernians Are to Revive Ancient Christmas Custom," Greensboro Daily News, December 25, 1938; and "Cooner John Parties All the Go with Young People," Daily Economist, December 5, 1906.

29. "The John Kooners Abroad," Wilmington Messenger, January 1, 1892.

30. The earliest mention of white Jonkonnu-inspired masquerades that I can find comes from 1887: "Local Dots,"

Morning Star, December 13, 1887. On the rise of and permits for white cooner parties, see, for instance, "Christmas," Wilmington Messenger, December 27, 1894; "Local Dots," Wilmington Morning Star, December 27, 1904; and

"Merry Masquerade Parties," Wilmington Dispatch, December 28,1909 . The number of "several hundred" permit comes from of unregulated Black celebrants in the street seemed less threatening. The year 1878 and subsequent years, then, marked a shift in perception that saw white observers move away from simple repudiation toward a deeply uncritical nostalgia that reduced African American people from political actors to mere Black bodies in performance. And, in turn, Jonkonnu became nothing more than holiday diversion, robbed of any threat that it had posed during the brief era of African American political ascendancy.

We can see the emergence of this perception clearly in many of the following years. A description of holiday celebrations in the city in 1878-79 maintained that "the only thing creating any stir at all was a band of about a dozen Kooners." They "paraded the streets, followed by a large crowd of negro men and boys. Just before dusk they assembled in front of the Market House, and the leader delivered a brief address on matters and things in general, which created much amusement." ${ }^{27}$ This last feature of the performance, a humorous speech in front of Wilmington's Market House, became a yearly part of the tradition. It is clear even from these relatively brief sketches that these speeches were intended to mock the overblown political rhetoric that played an increasingly large role in the life of the growing city.

It was sometime in these last decades of the nineteenth century that Jonkonnu was co-opted by white men and boys. ${ }^{28}$ Even as Black North Carolinians continued to evolve the practice in the post-emancipation city, white people adopted it as part of a wide-ranging culture of plantation nostalgia. Though there are very few sources about when this transformation happened, a plausible origin story comes from 1892. In that year, the usual "John Kooners ... consisting of young ladies and young men in grotesque costume and disguises" paraded through the city streets. In what seemed like a novel addition to the holiday celebrations, they were joined by a party of white men "dressed as negro dudes and dudines." Like the revelers they mocked, they too made speeches in front of the Market House and made a gentle ruckus around the city's downtown. But they were celebrated as part of the social scene, their names printed in the newspaper, a catalog of elite white family names. ${ }^{29}$ Even earlier hints at this appropriative practice abound, and by the turn of the twentieth century, a series of restrictions legitimated white "cooning" even as it targeted Black Jonkonnu. White revelers could easily stop into the police station and request a permit for their "cooning parties." Black people already under the constant and intensifying scrutiny of both human and spatial city infrastructures were undoubtedly unwilling to voluntarily offer their whereabouts to police. But white cooners were. By 1908 there were "several hundred" white men and boys on the streets, masked up or blacked up and going from door to door in a poor imitation of a longstanding Black cultural tradition. ${ }^{30}$

\section{Jonkonnu and Black Processional Culture}

Maggie Washington was born at this moment of transition. A generation removed from slavery, in 1887 Sarah and Stephen Jr. were well on their way to a kind of prosperity and security that had never been possible before, even for the population of free Blacks who had lived in Wilmington before the war. Maggie's parents, despite having only the income of Stephen Jr., had purchased a house on North Fifth Street, squarely in the center of the thriving Black neighborhood of Brooklyn. Itself an aspirational name, the neighborhood signified much of the promise of Maggie Washington's life at its inception. 


\section{$J O U R N A L$ OF FESTIVE}

\section{STUDIES}

"The Masqueraders," Wilmington Morning Star, December 30, 1908, though it is unclear if the writer is referring to permits issued for individual people or whole parties.

Regardless, the practice had clearly become commonplace in a short matter of time.

31. I will refer to these events, variously, as a coup d'état or a massacre. They are certainly not interchangeable but in fact reflect the variety of experiences of African American people in Wilmington at the time. For most of them, the most immediate and proximate concern was the violence being performed on Black communities. Coup better reflects the slightly longer-term effects and their impact on the city's structures and organization.

The literature on the Wilmington coup d'état of 1898 is still less voluminous than its comparative importance in American life would suggest. Among the first and most comprehensive historical studies of the period is Helen G. Edmonds, The Negro and Fusion Politics, 1894-1901

(Chapel Hill: University of North Carolina Press, 1951). Other studies of what was still being called a "race riot" followed, such as H. Leon Prather Sr., "The Red Shirt Movement in North Carolina 1898-1900," Journal of Negro History 62, no. 2 (April 1977): 174-84. The centennial of the coup brought specific and renewed attention to the events of November 1898 ,

including an excellent edited collection and a comprehensive state-sponsored study: David S. Cecelski and Timothy B. Tyson, eds., Democracy Betrayed: The Wilmington Riot of 1898 and Its Legacy (Chapel Hill: University of North Carolina Press, 1998).
Maggie Washington undoubtedly grew up watching the parades of the Good Samaritans, which her family was deeply involved in. It was likely from those same family members that she learned about and first participated in Jonkonnu. Her earliest years were marked by the waning of a strong processional culture, which had symbolized the cultural ascendancy of Black culture in Wilmington. These claims to and uses of the increasingly restricted spaces of the city marked her young life. But it was other, more violent, white supremacist claims to public space that reified these structural changes. Maggie Washington lived through the Wilmington massacre of 1898 and almost certainly witnessed the violent parade of white paramilitaries overthrowing the city. ${ }^{31}$

On November 10, 1898, Maggie Washington was three months shy of her twelfth birthday. On that morning, precisely when she usually would have been setting off for school, a mob was forming a few blocks away at the Wilmington light infantry armory. Right at 9:00 a.m., they marched to the offices of the Black-owned Record and burned it to the ground. Numbering perhaps as many as two thousand, this massive group, along with other angry and armed white men, spread throughout the city in the next minutes and hours. One particularly large group headed north toward Brooklyn, almost certainly passing by Peabody School, which Maggie attended with her younger sister Sarah. ${ }^{32}$

When the mob got to Brooklyn, they encountered an armed group of African Americans at the corner of Fourth and Harnett. Almost immediately, the groups opened fire on each other. They were just yards away from the Washington family home, situated between the Fourth and Fifth Avenue blocks and immediately adjacent to Harnett Street. ${ }^{33}$ Ordinarily Stephen Jr. would have been at work at the Cape Fear Lumber Company, just a block away from their house at Fourth and Harnett. In the weeks leading up to the coup, his had been a voice of conciliation. As part of the county's Republican Committee, he had signed a widely circulating letter that denounced controversial words written in the Post that served as the immediate spark for the November coup in Wilmington. ${ }^{34}$ It seems likely, though, that his moderation had turned to action by November 10 when shots were exchanged practically at the doorstep of his family home. If he was among the men defending Brooklyn from white marauders that day, it was never recorded or perhaps purposefully obscured. Part of the aim of the day's violence, like many acts of terrorism, was to obliterate institutions of memory making, a symbolic action made literal with the burning of the Record.

For someone like Maggie, growing up amid a family and a community where carnivalesque processions marked frequent and fleeting inversions of political power, this sudden and permanent coup must have likewise been literally unsettling. Each yearly Jonkonnu performance marked an ever-diminishing promise of a permanent reversal of the social order. The tentative, hard-won struggles of a generation-struggles whose gains had been eroding nearly as quickly as they were gained-were decimated in a matter of a few hours. This was itself a kind of inversion, an inauguration of the permanently regressive politics of white supremacy.

These changes were intimately linked to festive cultures like Jonkonnu or other processional celebrations of the Black community. The years between emancipation and the turn of the century offered some provisional promise for both the Washington family and the 


\section{J O UR N L OF FESTIVE}

\section{STUDIES}

32. US Census, 1900, New Hanover County, North Carolina, Wilmington, Enumeration District 64, p. 17, dwelling 291, family 458, Maggie Washington,

digital image, Ancestry.com; and Directory of Wilmington, NC [1897] (Richmond, VA: J. L. Hill's Printing, 1897), 12, 247.

33. My accounting of the day's events is based on LeRae Umfleet, 1898 Wilmington Race Riot Report (Raleigh, NC: Research

Branch, Office of Archives and History, NC Department of Cultural Resources, 2006), 121-55; Mulrooney, Race, Place, and Memory; and David Zucchino, Wilmington's Lie: The Murderous Coup of 1898 and the Rise of White Supremacy (New York: Atlantic Monthly Press, 2020).

34. "Mischief Making Simpleton," Semi-Weekly Messenger, August 26, 1898.

35. The Oxford English Dictionary cites that the first instances of the slang "coon" as offensive terms for African American people occurred in 1837 and 1862 , as an adjective and noun, respectively. The first of these, from 1837's novel Nick of Woods

is a fairly generalized insult that equates Black people with both snakes and raccoons. I read this as a new variation on an old theme: the portrayal of African American subjects as animals and animalistic. Snakes and raccoons suggest a characterization that is wily and duplicitous, but other attempts to

find similar use from the period suggest that this meaning (or this broader characterization) was not yet numerous. An 1862 reference, listed in the March 15, 1862,
Black communities of Wilmington. We can mark those gains in the material accumulation of houses and other property, in the elections to local office, and in steady paid employment in Wilmington's industrial economy. But the most visible gains of this interregnum period were the processional cultures that it allowed. Post-emancipation parades like those of the Good Samaritans represented an exercise in civic power. Even more centrally, Jonkonnu linked the cultural resistance of enslavement to the new social order as a renewed insistence on equality and license to public spaces. So the policing and regulation of these processional cultures represented a more gradual version of the white supremacist violence that erupted in Wilmington in November 1898. The spectacle of that violence was undergirded not just by centuries of enslavement but also by new and specific spatial and cultural arrangements that likewise enacted violence on the Black communities being built in Wilmington. To see how this culture of white supremacy was enacted, we can look again at the turn-of-the-century white appropriation of Jonkonnu.

\section{Remembering "Cooning"}

Our best sources for this appropriative practice are retrospective. Writing well into the midtwentieth century, multiple Wilmington men of prominent families recalled their turn-of-thecentury participation in what they called "cooning." Prior to 1898, Jonkonnu appeared in newspaper articles and other archival records under a variety of different monikers. "John Kuner" was the most prevalent of these identifiers, though an almost infinite variation of plays on the words "Kuner" and "John" appeared in an account at some point. In 1898 and subsequent years, there was a remarkably consistent shift toward identifying paraders as "cooners." This was clearly racialized language and a term intended to modify the long-standing spelling and use of "Kuner" with a word whose pejorative associations were part of an emergent vocabulary of Jim Crow. ${ }^{35}$ This abrupt, and systematic, shift toward explicitly racist language announced the arrival of new regimes of discrimination and regulation, as well as a characterization of the performance as one explicitly related to the performance of race. That is, starting in 1898, "cooning" was a practice not just by racialized minorities but of them as well.

Henry McKoy, one of the nostalgic mid-twentieth-century writers, detailed his own attempts at "cooning" or "coonering" in his 1957 book: "Well, I did it because my older brother had done it. My father had gone 'Coonering' before me and they appeared to have been pleased with it and had fun." In McKoy's telling, this is a tradition for young, elite white boys: "a group of from five to ten boys ranging in age from nine to sixteen would with great preparation gather together after supper, when the dark had fallen, and each would don whatever costume or garment he had been able to get." All of the clothes "had to be old and ill fitting." ${ }^{36}$ This marked a significant shift in the costuming practices at the center of Jonkonnu. They had begun as a hybridized masquerade that both preserved longstanding and cross-cultural traditions and mocked the ridiculous affectations of the planter aristocracy. Early Caribbean Jonkonnu costumes, like those documented by Isaac Mendes Belisario in Jamaica, were elaborate, ornate assemblages. They were modified in North America according to the availability of local materials. But they were no less vibrant and spectacular. Even the scarce images and descriptions of Jonkonnu costumes in the late antebellum and early postbellum periods make clear that they were significantly different in composition and material from everyday clothing (see fig. 1). ${ }^{37}$ 


\section{J O UR N A L}

\section{OF FESTIVE}

\section{STUDIES}

edition of Vanity Fair, is a more explicit racial characterization: that is, it seems to refer not back to the animalistic referent (the

raccoon) but to a broadening use of the word "coon" as a racial epithet. Still, this meaning of the word was clearly nascent at the time, as evidenced by its much more frequent occurrences in the postbellum period. It is also worth noting that it was in the two generations between the end of the Civil War and the beginning of the twentieth century that "coon" transitioned toward use as an explicitly racist term, rather than its former meaning ("a sly, knowing fellow"), which seems to have tended to be a reading based on class.

36. Henry McKoy, Wilmington, N.C.: Do You Remember When?

(Greenville, SC: Keys Printing, 1957), 143, 141.

37. In addition to the 1891 image from Rebecca Cameron included above, there are a few other snatches of description of Jonkonnu costumes like one recalling "the harlequin of past Christmas times," clad in brightly colored strips of cloth: "Poor Cooner John," Fayetteville Weekly Observer, December 31, 1903.

38. "Local Dots," Wilmington

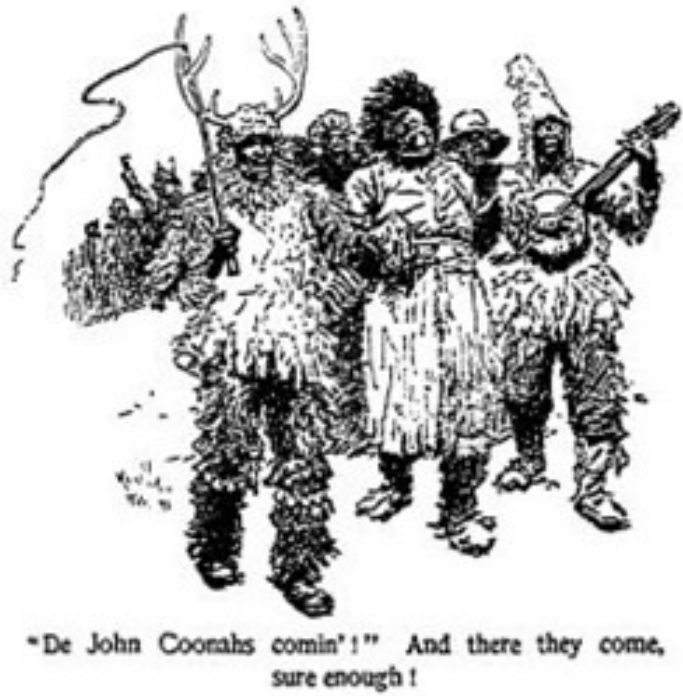

Figure 1. A postbellum depiction of plantation Jonkonnu. In Rebecca Cameron, "Christmas on an Old Plantation," Ladies' Home Journal 9, no. 1 (December 1891), 5.

McKoy and his contemporaries instead formed a vernacular that focused on imitation of the imitation not of the bright, vibrant costumes of Jonkonnu but of the everyday working clothes of the African American people whose own masquerades they were imitating.

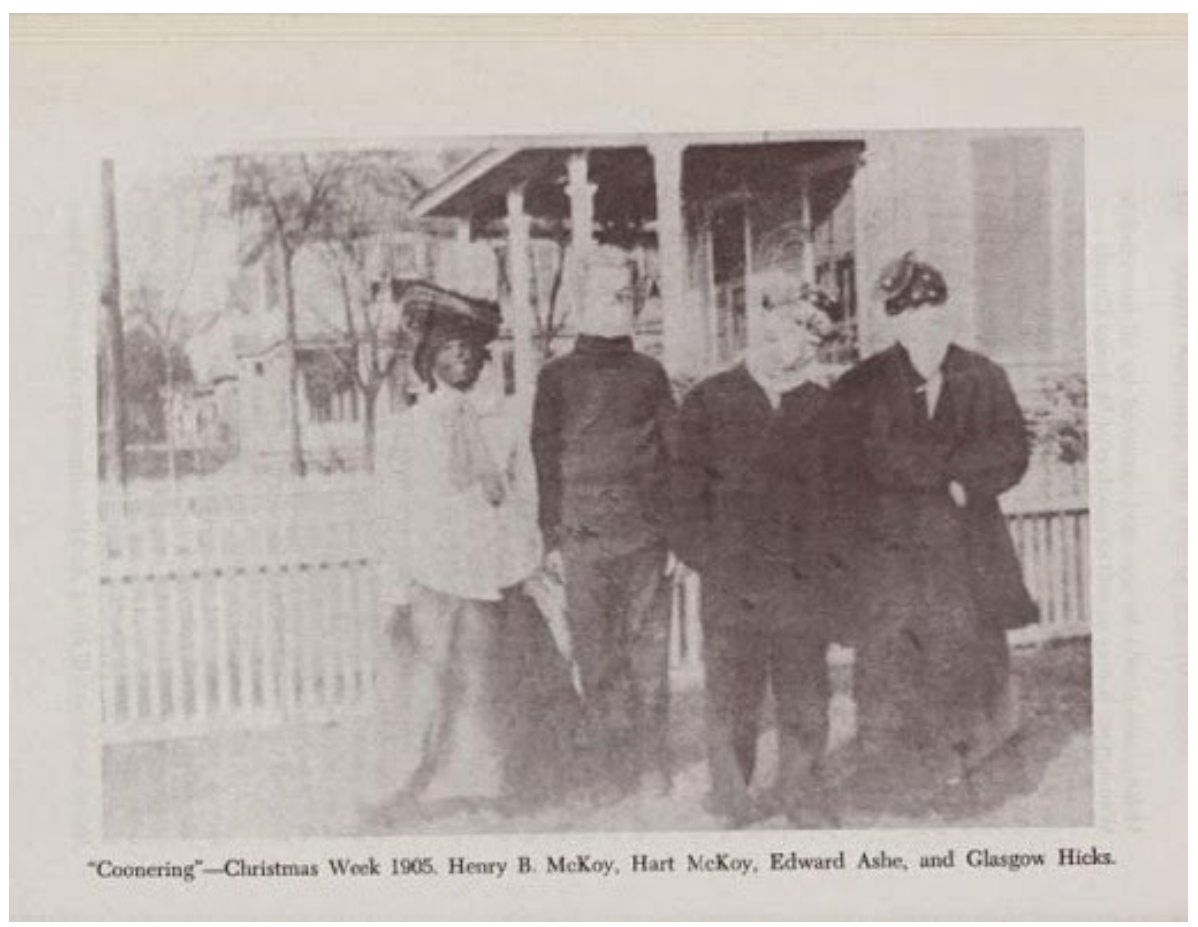

Figure 2. Four young boys "coonering" in Wilmington, 1905. In Henry McKoy, Wilmington, N.C.: Do You Remember When? (Greenville, SC: Keys Printing, 1957), 143.

Looking at the hazy picture of McKoy and his friends taken in 1905 (fig. 2), it is clear that they are attempting to inhabit other personages. McKoy stands to the far left, wearing what appears to be his interpretation of the stereotypical "mammy" character. He is in blackface, with the wide grin 


\section{$J O U R N A L$ \\ OF FESTIVE \\ STUDIES}

Morning Star, December 27, 1904; and "The Masqueraders," Wilmington Morning Star, December 30, 1908.

39. Louis Moore, Stories Old and New of the Cape Fear Region (Wilmington, NC: Wilmington Printing, 1956), 74.

40. In addition to those already cited, there were several other writers who exhibited nostalgia

for the practices of earlier

North American Jonkonnu.

See, for instance, Dougald Mac Millan, "John Kuners," Journal of American Folk Lore 39 (1926): 53-57; C. F. Dozier, "The Kooners," Wilmington Morning Star, April 15, 1922; "Letters to the Editor," Wilmington Morning Star, April 5, 1922; B. F. Penny, "Christmas Greeting," Wilmington Dispatch, December 22, 1910; and J. R. Myrover, "How Our Fathers Managed," Charlotte Observer, January 26, 1908.

41. "Negro Was Drowned," Wilmington Messenger, August

23, 1906; and New Hanover County, North Carolina, Marriage register, p. 154-e, MerrickWashington, 1907, North Carolina State Archives, Raleigh, North Carolina.

42. "He Will Probably Die," Wilmington Messenger, September 4, 1890.

\section{$H$

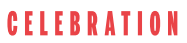

that is the chief characteristic of the racist figure. The rest of his getup-a kerchief tied over his head, a slightly oversized white blouse, and a floor-length skirt-complete his transformation. In the broader context of Jonkonnu's appropriative transformation, this is a telling image. McKoy is not imitating a Black woman outright: he makes it clear throughout his reminiscence that he and his family understood the "John Kuner" as a stock figure that was itself an imitation. So his costume consisted of a young, wealthy white boy attempting to embody the persona of a Black male Jonkonnu performer who was himself dressed in women's clothes.

It is not quite that neat of course, since in reality McKoy's costume is a kind of racist assemblage, an appropriation of two figures who undoubtedly represented a significant portion of his understanding of race. McKoy and others materialized this stereotypical understanding through their own costuming and processional practices. By the early twentieth century, then, Jonkonnu in Wilmington was transitioning to "cooning," a white performance of stereotyped blackness. This kind of celebration was not limited to McKoy's circles but nearly ubiquitous in Wilmington at the holidays. The 1904 "merry masqueraders" consisted of "about a dozen cooner parties" and the 1908 parades were referred to as "throngs." ${ }^{38}$ They were numerous, and this was already a widely practiced tradition among white Wilmingtonians. And McKoy was only one of the aged chroniclers of youthful cooning. Nostalgia for the practice of their youth became a veritable industry among wealthy whites from the turn of the century on. Their longing centered on both their own attempts at cooning and what they perceived as the more authentic practice of Jonkonnu. The irony of this, of course, is that it was their very own practices of appropriation and the accompanying regulation that caused the much admired "primitive" custom of Jonkonnu to die out. The writers advanced a racial essentialism that saw "John Kuners" as exemplars of a characteristic "spirit of gaity [sic], fun, and levity particularly their own." ${ }^{39}$ This was the carefree figure that these men and boys sought to inhabit in their own performances of cooning. ${ }^{40}$

Jonkonnu's turn-of-the-century transformation sought to center whiteness. Like other civic, cultural, and social institutions, Jonkonnu was remade following the white supremacist logics of appropriation and obliteration. Washington did not fit easily into this new Wilmington. She was both Black and a woman, not a symbol of matronly comfort but a vivid and subversive figure. Undoubtedly it was these characteristics, in part, that led to her arrest and her profile in the newspapers as part of a notorious criminal element, a uniquely sexualized criminality associated with any Black woman not adherent to both the actual and extrajudicial laws governing the use of space. For Washington, these transformations of space and culture in Wilmington were not abstractions but a large part of the governing force of her life.

\section{Maggie Washington's Wilmington}

Maggie Washington was twenty years old when she married William H. Merrick in 1907, the year after her father drowned while navigating logs into the lumber yard from the Cape Fear River. ${ }^{41}$ It is likely that she and William also met through the lingering connections formed in the Good Samaritans-his father had been a member too. ${ }^{42}$ After her marriage, Maggie Merrick is difficult to trace for a few years. Her change of name, compounded by the fact that there were at least two other William Merricks in Wilmington at the time (one of whom was married to a woman sometimes also named Maggie) means that even the incidental mentions of her life go largely unreported. Her elusion of this sort of attention is telling. She darts in and out 


\section{$J O U R N A L$ \\ OF FESTIVE}

STUDIES

43. By comparison, the increasing solidification of tenancy in the countryside was premised in part on proximity and surveillance.

Even on larger plantations with plots of land at a significant remove from the owner's house, surveillance was embedded into the work process itself, which necessarily limited spatial mobility because of the farmer's stake in the crop. Wilmington and other cities allowed African Americans to avoid this particular form of individual scrutiny.

44. "Woman Was Masquerading," Morning Star, December 28, 1911.

45. "The Recorder's Court," Dispatch, December 28, 1911; and

"Woman Was Masquerading," Morning Star, December 28, 1911.

46. "Woman Was Masquerading," Morning Star, December 28, 1911.

47. "In the Mayor's Court," Wilmington Messenger, August 9, 1904; and "Will Abate the Nuisance," Wilmington Messenger, May 10, 1900. of notice, seemingly deigning to appear only in the most comprehensive and official sources. This was certainly part of the draw of a city like Wilmington and perhaps contributed to Maggie Washington Merrick's continued presence there. It was a place that allowed and even invited some anonymity from official scrutiny. It was dense enough to allow institutions of community to form and still small enough that cross-generational connections continued to matter. The landscape of the city itself then offered tenuous refuge from the most frequent forms of scrutiny and surveillance. But its changes in physical infrastructure intensified attention to Black movement, and the constant threat of violence rendered the southern city less and less habitable for people like Washington. ${ }^{43}$

The reports of her arrest are littered with misinformation and innuendo. If we take the summary of her arrest report as it appeared in the newspapers at face value, she was a "resident of the notorious alley across the street" from the city's chief market. ${ }^{44}$ Her arresting officer, Frank George, was "of the opinion that she was ... dressed up for no good purpose" and perhaps warranted a more substantive charge than the simple citation for "being disguised on the street without a permit." 45 George's implication was clear: he suspected Washington of prostitution. Even given all evidence to the contrary-her "men's attire" and the long tradition of Jonkonnu on this particular day-George jumped immediately to a gendered, sexualized criminality. ${ }^{46}$ Certainly part of this was a general belief in Black female licentiousness, akin to the myths about rampant Black male sexuality, that circulated in southern white communities. But the particular history of this characterization in Wilmington stretched back more than a decade and spoke to the emergence and regulation of African American leisure spaces.

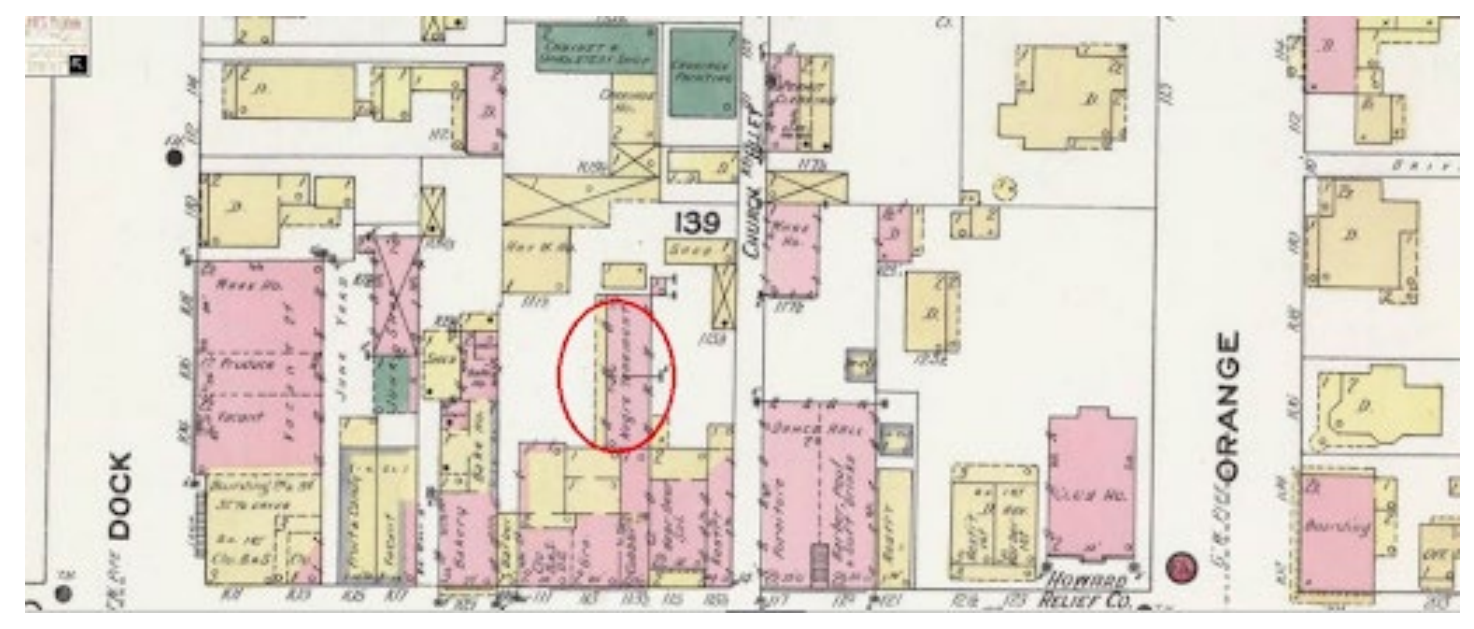

Figure 3. Detail of 1910 Sanborn Fire Insurance map of Wilmington showing a "Negro Tenement" situated on Church Alley. North Carolina Collection, Wilson Special Collections Library, University of North Carolina at Chapel Hill.

What George referred to as "the notorious alley" (fig. 3) was colloquially known as "Racket Alley" (after an old store that had been located there) or officially as "Church Alley." Around the turn of the twentieth century, Racket Alley became a central focus of police and public officials who viewed it as a "den of infamy" that contributed to "rowdyism on the streets." ${ }^{47}$ And though authorities were concerned with illegal drinking and gambling here, their principal focus was on prostitution. Policing Black women, automatically perceived as prostitutes, became a crucial part of reinforcing white spatial hegemony. This sort of control was heightened in the wake of 


\section{$J O U R N A L$ OF FESTIVE STUDIES}

48. "Local Dots," Wilmington Morning Star, March 22, 1899.

49. I base this reading of the tenement on the Sanborn maps

cited here. My attempts to locate the alley with the help of local historians were thwarted: it was enclosed sometime in the twentieth century. The site upon my last visit was home to a souvenir shop: this part of town has been transformed into a center of tourist charm. It was still a center for bootlegging and blind tigers in the 1920s: "Found Dividing Loot, Three Make Escape," Wilmington Morning

Star, February 7, 1901; and "Get Jag from Wood Alcohol," Wilmington Morning Star, April 25, 1920. the 1898 coup. Among the first results of this newly intensified police attention was the arrest of Tillie Taylor in early 1899. She was "charged with keeping a disorderly house in 'Racket' alley." Her punishment was banishment from the city. In the court of the new mayor "she was given until Monday to leave town." ${ }^{\text {"8 }}$ Certainly Taylor's was an extreme example brought on in part by heightened paranoia and regulation. But we could say the same of Washington's arrest a dozen years later. Clearly, the instruments of official power in Wilmington were directed toward the regulation of Black women's movement. And the vocabulary and justification that they formed for enacting those actions of surveillance and policing was one that both sexualized and criminalized Black female bodies. Racket Alley, that "notorious alley," became a localized symbol of crime in the city. It acted as an origin point that police could continuously raid and for which they could blame for crime spreading throughout the city.

So, it may well have been that Maggie Washington did not in fact set out from Racket Alley on the night of December 26, 1911. Her supposed residence there could have been an assumption on the part of the police and the newspapers and owed to their associations of the area with the only kind of Black female criminality legible to them in and around the city. Regardless of her living situation, by 1911, her marriage to Merrick had ended, either in divorce or death. While there are no records of either, Maggie Washington was arrested under her maiden name and remarried a few years later. It is entirely possible that after her marriage to Merrick ended, she found herself living in the "Negro tenement" that was in the rear of a cobbler shop on Racket Alley.

Standing just steps away from the Cape Fear River and in an industrial part of town, this residence was a conspicuous exception to the character of the area. With no official address and an entrance likely through the narrow cobbler shop of Cohn Hyman at 113 1 $1 / 2$ Front Street, this was undoubtedly a place that would have given the perception of transience and impermanence, a likely landing place for people moving into and out of the city or otherwise seeking to avoid the scrutiny and attention that was more likely to fall on their heads. ${ }^{49}$

So if indeed Maggie Washington did live here and did set out from here on the night that she was arrested, she may have gone one of several different ways. The most direct route would have taken her north on Front Street, to a crossing over Market Street. This marked an unofficial boundary between the industrial district she lived in and the better part of town that held hotels, the Masonic Lodge, and many of the larger houses in town. Proceeding past the fine buildings lining this northern corridor of Front Street, Washington must have turned east on Princess Street past boarding houses, pool halls, the offices of the Wilmington Morning Star, and the seats of power: the courthouse and jail where her night ended. Even if she had opted to avoid these main avenues and traverse less populated roads, her options were limited. Central Wilmington was a fairly tightly gridded city, hemmed in by the Cape Fear on two sides and limited in size and scope by both its surroundings and planned patterns of development. These designs limited Maggie Washington's mobility to a number of proscribed options and foreclose our ability to entirely reconstruct her procession on the night of December 26, 1911. Faced with a paucity of interpretive options, we resort to the most direct route, knowing that this is a contradiction of the free roaming nature of Jonkonnu, whatever her own understanding and interpretation of it. Recorded in contemporary maps and other sources are a few possibilities for Maggie Washington's route the night of her arrest. But more telling are the absences, the factors that limit 


\section{J O URNAL}

OF FESTIVE

\section{STUDIES}

50. Henry G. Connor, George Davis (Wilmington, NC: Cape Fear Chapter of the United Daughters of the Confederacy, 1911), 29.

\section{$H$

our understanding of Maggie Washington either as a historical figure or in the context of her own time.

As Maggie Washington walked, whatever route she took led her through a landscape marred by the symbols of white power. That symbolic power, however potent, was also overlaid with the omnipresent threat of surveillance and bodily violence. The year 1911 acts as a perfect encapsulation of transformations in the landscape of the city that saw its emergence as a thoroughly "modern" southern city. The first of these were physical infrastructural improvements and a kind of quantifiable economic boosterism that we can see in texts like Sanborn Fire Insurance maps and chamber of commerce pamphlets. These changes were coincident with other modifications to the landscape of the city, principally the construction of monuments to the Confederate past. Together, these changes constituted an infrastructural white supremacy. These infrastructures, including uneven distribution of city services and the construction of memorials to the Lost Cause, transformed Wilmington into a city hospitable principally to its white citizens alone.

This movement-the erection of monuments to the Confederate cause and political figures of the exclusive past-was one that began particularly early in Wilmington. As a manifestation of the newly dominant white celebratory culture, it both reinforced white visions of the past and obliterated other celebratory traditions. This was particularly the case for the ephemeral, eventbased festive cultures of Wilmington's African American communities. A few months before Wilmington had dedicated a new eight-foot-high statue to George Davis, the Wilmington resident who had been the attorney general of the Confederacy. This new monument was in the middle of town. Situated at Third and Market, the figure of Davis watched over passersby, almost certainly including Washington in his far-reaching gaze on the night of December 26. When the statue was dedicated on April 20, 1911, it was with a long, ponderous, and nostalgic speech by the North Carolina jurist Henry Connor. In a speech representative of the racist politics of the day, Connor looked "backward over the days of reconstruction, military rule, and negro supremacy" to find the "clear white light" of white, male southern loyalty. Arguing against the depiction of Confederates as disloyal, Connor instead insisted that it was a steadfast commitment to their own moral principles that led to "these days of restored nationality." ${ }^{50}$ Certainly it was these kinds of overblown speeches that John Kuners had long mocked during their Market House speeches.

This statue of Davis, perched high above one of the city's central intersections, was one of many that cast in granite, marble, and bronze a vision of an ordered and exclusionary landscape. This artistic rendering of a historicized racism seemed to hold court over the spatial functions of the central city. As an omnipresent symbol, it matched the reality of police presence and normalized surveillance. This was one part of a new system of spatial control that arose in early twentiethcentury Wilmington.

This was likewise true of physical infrastructural developments. The advent of Jim Crow was materialized first in city streets with the advent of spatial segregation. This "sorting out" occurred not only on the level of the homes and neighborhoods but also on the more localized level of street lights, sewer service, and other infrastructural changes. ${ }^{51}$ But, crucially, it is also in the representations of cities that we can find a new vision made real. As with other elements of social control, there was both a very real set of priorities that created segregated districts without 


\section{$J O U R N A L$ OF FESTIVE}

\section{STUDIES}

51. Thomas Hanchett, Sorting Out the New South City: Race, Class, and Urban Development in Charlotte, 1875-1975 (Chapel Hill: University of North Carolina

Press, 1999).

52. William Lord De Rosset Jr., Wilmington, North Carolina, and Vicinity (Wilmington, NC: W. L. DeRosset Jr., 1910), 7, NC Collection, Wilson Special Collections Library, University of North Carolina at Chapel Hill.

53. I. J. Isaacs, The City of Wilmington, the Metropolis and Port of North Carolina: Its Advantages and Interests, Also a Series of Sketches of Representative Business Houses (Wilmington, NC: Wilmington Stamp \& Printing, 1912), 3, NC Collection. 54. Ibid., 29.

55. I also include racial terror lynchings. Though New Hanover

County (where Wilmington is located) did not have other documented lynchings after 1898 , neighboring counties like Onslow and Pender did. The impacts of these acts of racial terror were certainly felt in Wilmington. Seth Kotch and Elijah Gaddis, A

Red Record, lynching.unc.edu (accessed June 20, 2020).

56. Mulrooney offers a particularly useful portrait of MacRae as a planner of the coup and particularly his relationship to his co-conspirators. See Mulrooney, Race, Place, and Power, 128-32. Also useful in setting MacRae in the broader context of white southern manhood and its responses to the New South is Glenda Gilmore, Gender and Jim the amenities of city life and a symbolic register in which the city was represented as a place absent of Black life.

The writing of this erasure came from several sources simultaneously. Early twentieth-century booster literature, designed to attract both tourists and industrial investment, mentioned Black people only as another of the area's natural resources. In their telling, the city possessed "an abundance of cheap labor ... sufficient inducement to settlers and capitalists to come to Wilmington to live." 52 Other such inducements were Wilmington's moves toward the physical infrastructures of a modern city. As of 1911, Wilmington was soon to install a sewer system, had a paid fire department, and was requiring all sidewalks to be paved. And in recent years, the water system had been expanded to such an extent that another business booster could claim "water is practically now laid on to all the parts of the city." ${ }^{53}$ Through the eyes of its businesses and political leaders, Wilmington was a model city. A company then called Tidewater Power was established in 1907 and started making improvements to street cars and gas and electric service. Tidewater Power was a consolidation of previous companies and its intent was to transform Wilmington more efficiently and with greater speed than many companies working toward common if sometimes competing goals. ${ }^{54}$ This modernization and transformation of the city was one designed to make it more suitable for its white residents.

In this, it bears comparison in outcome, if not method, to the events of 1898. Both were designed as part of a spatial white supremacy that saw enactment in the seemingly minor changes of regulation, enforcement, and surveillance, and eruptions of racial violence..$^{55}$ Often, they were undertaken by the same people. Indeed, the chief architect of Wilmington's infrastructural evolution in the early twentieth century was none other than Hugh MacRae, the white supremacist and architect of the 1898 coup. ${ }^{56}$ MacRae's plans for the city were expressed clearly in the November 1898 eruption of violence and in the more gradual unfolding of infrastructural violence in the years ahead. He would remake the city in both temporal scales, working over the long term to help exacerbate existing inequalities by failing to extend these increasingly basic services to the places built and frequented by African Americans. In twentieth-century Wilmington, then, we see a dual legacy of official violence. Each of these forms was adopted and modified in turn in the coming century, inaugurating a cycle of extreme violence tempered by years of relative calm during which basic rights and privileges were stepped back.

These spatial changes were also made representational in the growing city. New investors and industry called for better maps of the city and its resources. The Sanborn Company Fire Insurance maps in particular recorded the city exactingly. Long a staple for academic researchers due to their precise level of detail, Sanborn maps served as both spatial and economic encapsulations of a city. They defined what was of value and what was not worth insuring. They are like other maps, albeit without any illusion of objectivity. Still, they can prove useful to help animate a place whose contours have changed significantly. Returning to Washington's journey on December 26, 1911, we can surmise a good bit more about her probable route. As she moved past the courthouse and jail, Washington entered into an almost exclusively residential section. As represented on the map, these are larger, single-family homes set back from the road on large lots with expansive porches. ${ }^{57}$ These houses held families principally of the middle class, not the city's elite who would have been the target of Jonkonnu parades 


\section{$J O U R N A L$ \\ OF FESTIVE}

\section{STUDIES}

Crow: Women and the Politics of White Supremacy in North Carolina (Chapel Hill: University of North Carolina Press, 1996), 65-77.

57. "Insurance Maps of Wilmington, N.C., June 1910: North Carolina Maps," Fire insurance (New York: Sanborn Map, June 1910), sheet 2, NC Collection.

58. "Woman Was Masquerading," Morning Star, December 28, 1911.

59. "Insurance Maps of Wilmington, NC, June 1910: North Carolina Maps," Fire insurance (New York: Sanborn Map, June 1910), sheet 4, NC Collection. wandering the streets. As she moved past these houses, if she moved past these houses, Washington arrived at a boundary of sorts. After Princess crossed Tenth Street, the houses got smaller. Still made out of wood, many of them were duplexes housing multiple families. The others might charitably be called modest, the small houses of painters and carpenters and other working professionals. This was mostly a Black neighborhood but with many white homes interspersed throughout. Likely many of these were newcomers, brought to the city by its periodic construction booms and industrial jobs.

One block more and Washington's procession brought her to a solidly African American neighborhood, one anchored by the Eastern Star Lodge and populated with the wooden-framed houses of domestics, cooks, and laundresses. For the purposes of city officials and mapmakers, this was a marginal neighborhood. That marginalization was made actual on the Sanborn maps. The one piece of geographic information we do have about the night of Washington's arrest is her location when she was picked up by the police. She was arrested at "12th and Princess streets. ${ }^{158}$ But, in a piece of symbolism so potent as to be overdetermined, this intersection does not exist. That is, it is not represented on the map. Clearly, surveyors did not find anything of value in the largely residential, largely poor neighborhood. This kind of devaluation is hardly shocking, though it is representative of broader trends in a time when white supremacist governance was coming to control even the most quotidian aspects of life for Black people. Infrastructural improvements and the representation of that infrastructure do that work implicitly, but in this absence, we see an active erasure taking place. ${ }^{59}$ This absence is itself an expression of materiality, and one particularly suited to Jonkonnu and the space of Wilmington at the turn of the twentieth century. The willful obliteration of both material and symbolic traces of Black festive culture makes our recovery and understanding of it a difficult task.

Ephemeral by nature, the material traces of festive occasions most often persist in the preservation of intangible tradition. But Washington was among the last in a line of Black processional celebrants in Wilmington and in the American South more broadly. The tradition she took part in was not lost but rather intentionally appropriated and erased. So, perhaps ironically, it is the material remainders of the very movements that worked against these traditions of Black processional mobility that can offer some accounting of this history. Despite changes and additions, the basic grid of Wilmington is largely unchanged since Washington's time. The Davis statue is still there and still squarely on the route of the many tourists and city residents who traverse downtown on foot. There are changes too: Racket Alley is now closed in and the neighborhood around it consisted mostly of shops and restaurants on my last visit. Perhaps most telling though is that the area where Washington was arrested, the hinterlands of the city not deemed important enough to be mapped, are, if not unchanged, still peripheral to the city as a whole.

In December 2015, I recreated Washington's probable route through the city (fig. 4). My endpoint, like hers, was at Twelfth and Princess. To me, as undoubtedly to the surveyors of a century prior, it seemed empty. Many of the remaining buildings and businesses were surrounded by high chain-link fences, and papered over windows and empty lots predominated. But clearly it was once a place of habitation and community. The now empty storefronts suggest as much.

Journal of Festive Studies, Vol. 3, 2021, 72-91. https://doi.org/10.33823/jfs.2021.3.1.66 


\section{$J O U R N A L$}

OF FESTIVE

STUDIES

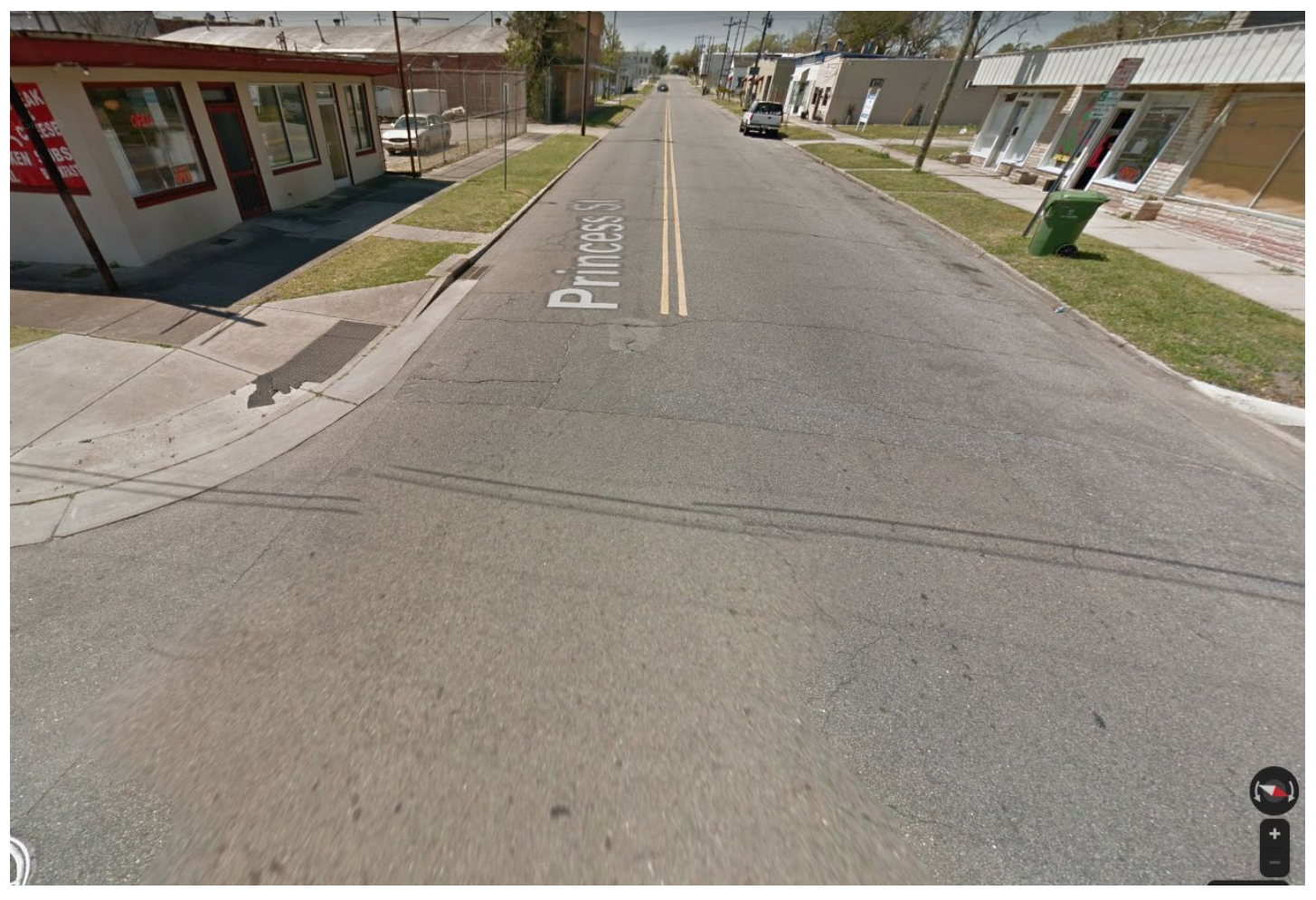

Figure 4. A contemporary view of the intersection of Princess and Twelfth Streets. Google Maps (accessed January 2017).

The same forces of disinterest in neighborhoods like this one more than a hundred years ago helped dictate its direction in the years since. Amid its material decline and the demonstrated disinterest in places like this, we can overlap the traces of enlivening festivity of people like Maggie Washington. Legible traces of her presence and of the processional cultures she participated in are not visible here. But they persist in the material elements of her world, the places she lived in, walked through, celebrated, and mourned in.

\section{BIBLIOGRAPHY}

Abrahams, Roger D. Singing the Master: The Emergence of Afro-American Culture on the Southern Plantation. New York: Pantheon Books, 1992.

Bakhtin, Mikhail. Rabelais and His World. Translated by Helene Iswolsky. Cambridge, MA: MIT Press, 1968.

Beckwith, Martha Warren. Christmas Mummings in Jamaica. New York: American Folk-Lore Society, 1928.

Belisario, Isaac Mendes. Sketches of Character in Illustration of the Habits, Occupation and Costume of the Negro Population in the Island of Jamaica. Kingston, Jamaica: Published by the artist at his residence, 1837-38. 


\section{J O UR N A L}

OF FESTIVE

STUDIES
Bilby, Kenneth. "Surviving Secularization: Masking the Spirit in the Jankunu (John Canoe)

Festivals of the Caribbean." New West Indian Guide 84, nos. 3-4 (December 1, 2010): 179-223.

Carraway, Gertrude S. "New Bernians Are to Revive Ancient Christmas Custom." Greensboro Daily News, December 25, 1938.

Cecelski, David S. and Timothy B. Tyson, eds. Democracy Betrayed: The Wilmington Riot of 1898 and Its Legacy. Chapel Hill: University of North Carolina Press, 1998.

Connor, Henry G. George Davis. Wilmington, NC: Cape Fear Chapter of the United Daughters of the Confederacy, 1911.

Craton, Michael. "Decoding Pitchy-Patchy: The Roots, Branches, and Essence of Junkanoo." Slavery \& Abolition 16, no. 1 (1995): 14-44.

Directory of Wilmington, NC [1897]. Richmond, VA: J. L. Hill's Printing, 1897.

Dirks, Robert. The Black Saturnalia: Conflict and Its Ritual Expression on British West Indian Slave Plantations. Gainesville: University Press of Florida, 1987.

Dozier, C. F. "The Kooners." Wilmington Morning Star, April 15, 1922.

Edmonds, Helen G. The Negro and Fusion Politics, 1894-1901. Chapel Hill: University of North Carolina Press, 1951.

Fabre, Geneviève. "Festive Moments in Antebellum African American Culture." In The Black Columbiad: Defining Moments in African American Literature and Culture, edited by Werner Sollors and Maria Diedrich, 52-63. Cambridge, MA: Harvard University Press, 1994.

Fenn, Elizabeth A. "'A Perfect Equality Seemed to Reign': Slave Society and Jonkonnu." The North Carolina Historical Review 65, no. 2 (April 1988): 127-53.

Gilmore, Glenda. Gender and Jim Crow: Women and the Politics of White Supremacy in North Carolina. Chapel Hill: University of North Carolina Press, 1996.

Hanchett, Thomas. Sorting Out the New South City: Race, Class, and Urban Development in Charlotte, 1875-1975. Chapel Hill: University of North Carolina Press, 1999.

Jacobs, Harriet. Incidents in the Life of a Slave Girl. Boston: Published for the author, 1861.

Levine, Lawrence W. Black Culture and Black Consciousness: Afro-American Folk Thought from Slavery to Freedom. New York: Oxford University Press, 1977.

Long, Edward. The History of Jamaica. London: Printed for T. Lowndes, 1774.

Mac Millan, Dougald. "John Kuners," Journal of American Folk Lore 39 (1926): 53-57.

McKoy, Henry. Wilmington, N.C.: Do You Remember When? Greenville, SC: Keys Printing, 1957.

Moore, Louis. Stories Old and New of the Cape Fear Region. Wilmington, NC: Wilmington Printing, 1956.

Mulrooney, Margaret M. Race, Place, and Memory: Deep Currents in Wilmington, North Carolina. Gainesville: University Press of Florida, 2018. 
J O URNAL

OF FESTIVE

STUDIES
North Carolina Collection, Wilson Special Collections Library, University of North Carolina at Chapel Hill.

Penny, B. F. "Christmas Greeting." Wilmington Dispatch, December 22, 1910.

Prather, H. Leon Sr. "The Red Shirt Movement in North Carolina 1898-1900." Journal of Negro History 62, no. 2 (April 1977): 174-84.

Smalligan, Laura M. "An Effigy for the Enslaved: Jonkonnu in Jamaica and Belisario's Sketches of Character." Slavery \& Abolition 32, no. 4 (2011): 561-81.

Umfleet, LeRae. 1898 Wilmington Race Riot Report. Raleigh, NC: Research Branch, Office of Archives and History, NC Department of Cultural Resources, 2006.

US Census, 1870, New Hanover County, North Carolina, Wilmington, digital image, Ancestry.com. US Census, 1900, New Hanover County, North Carolina, Wilmington, digital image, Ancestry.com. Walser, Richard. "His Worship the John Kuner." North Carolina Folklore Journal 47, no. 2 (2000): 97-110.

Warren, Edward. A Doctor's Experiences in Three Continents. Baltimore, MD: Cushings \& Bailey, 1885.

Wilmington, N.C. Directory, 1905. Richmond, VA: Hill Directory, 1905.

Work, Monroe N., Thomas S. Staples, H. A. Wallace, Kelly Miller, Whitefield McKinlay, Samuel E. Lacy, R. L. Smith, and H. R. Mcllwaine. "Some Negro Members of Reconstruction Conventions and Legislatures and of Congress." Journal of Negro History 5, no. 1 (1920): 63-119.

Zucchino, David. Wilmington's Lie: The Murderous Coup of 1898 and the Rise of White Supremacy. New York: Atlantic Monthly Press, 2020.

\section{AUTHOR BIO}

Elijah Gaddis is an assistant professor of history at Auburn University where he teaches courses on material culture, the built environment, and museums. He holds a doctorate in American studies from the University of North Carolina at Chapel Hill. He is currently completing his first book, "Gruesome Looking Objects: Material Culture and the Landscape of Lynching."

\section{OPEN ACCESS}

(C) 2021 by the author. Licensee $\mathrm{H}$-Net: Humanities \& Social Sciences Online. This article is an open access article distributed under the terms and conditions of the Creative Commons Attribution-NonCommercial-NoDerivs 3.0 license (https://creativecommons.org/licenses/bync-nd/3.0/) 
J OURNAL

\section{OF FESTIVE}

STUDIES
HOW TO CITE

Gaddis, Elijah. "Processional Culture and Black Mobility in Maggie Washington's Wilmington." Journal of Festive Studies 3 (2021): 72-91. https://doi.org/10.33823/jfs.2021.3.1.66

The Journal of Festive Studies (ISSN 2641-9939) is a peer-reviewed open access journal from $\mathrm{H}$-Celebration, a network of $\mathrm{H}$-Net: Humanities \& Social Sciences Online, and is the inaugural

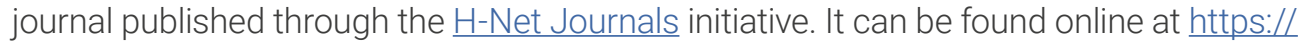
journals.h-net.org/jfs. 